\title{
Economics
}

Economics and Sociology

Occasional Paper \#725

\section{ECONOMIC DISEQUILIBRIA AND RURAL \\ FINANCIAL MARKET PERFORMANCE \\ IN DEVELOPING ECONOMIES}

\author{
by \\ Compton Bourne \\ and \\ Douglas H. Graham \\ Revised \\ June 1980
}

Agricultural Finance Program

Department of Agricultural Economics and Rural Sociology

The Ohio state University

2120 Fyffe Road

Columbus, Ohio 43210 
ECONOMIC DISEQUILIBRIA AND RURAL FINANCIAL

MARKET PERFORMANCE IN DEVELOPING ECONOMIES*

Financial markets are expected to contribute to rural development in developing economies by improving the quantity and quality of rural savings, and by the provision of credit in amounts and forms that enhance productive capacity and rural equity. However, mounting evidence from many countries leads to the conclusion that rural financial markets are not fulfilling these expectations (See for example, Adams, 1979; Adams and Ladman, 1978; De Araujo and Meyer; Vogel; Ladman and Tinnermeir; and Desai). Financial savings have not grown significantly, and poor loan repayment performance and problems of funding have prevented the sustained growth of rural credit. Indeed, in several countries, such as Bangladesh, Ghana, and Jamaica, rural financial markets are in a state of acute depression or near collapse.

Among the various approaches taken to diagnose the decline in the viability and performance of rural financial markets are in-depth analyses of specific programs and institutions. These studies invariably highlight the weakness of program design and managerial skills, inappropriate coordination with other policies, poorly defined or inconsistent objectives and, in general insufficient appreciation of the limits of the possible in trying to rapidly change or expand the size and composition of a credit program's portfolio with present managerial skills and resources. Policy recommendations emerging from these "intra- 
project" evaluations emphasize the need for innovations in deposit facilities and savings mobilization (Adams, 1978), better credit delivery systems (Adams and Ladman, 1979), through improved credit appraisal methods and more effective loan monitoring and loan recovery procedures (e.g. Gonzalez-Vega and Tinnermeir). Finally the need to institute more flexible interest rate policies, thereby reducing the wide gap between low lending rates and high lending costs is frequently advised (Adams, 1978; Datey). The net effect of these concerted efforts are expected to guarantee a viable self-sustaining set of financial programs contributing to the recovery of rural financial markets.

For the most part these policy recommendations are based on sound diagnoses and their implementation called for. In a relatively healthy economy experiencing positive rates of growth, 1ittle to moderate inflation and relatively stable exchange rates and balanced trade, such "intra-project" reforms are both necessary and sufficient to secure a recuperation of rural financial institutions and programs. In this setting the potential for the recovery of rural financial markets is apparent.

However, these approaches are unlikely to be adequate in situations of widespread and acute economic disequilibria. In these situations, the poor performance of the financial sector is conditioned by underlying problems in the real sector of the economy. In the latter circumstances financial sector reforms by themselves are too partial and narrow in focus. They are hardly sufficient conditions for the 
recovery of rural financial markets when the general economic environment and related policy instruments exert much stronger influence on the success or failure of a credit project than specific intra-project reforms.

We argue that macroeconomic disequilibria transmit

themselves to rural financial markets through their effects on farm output, profits, and debt and savings capacity, as well as through their effects on debt service and amortization requirements. Careful consideration of these linkages is necessary for fuller understanding of the problems of rural financial markets and for the formulation of appropriate rural development policies.

The paper begins by identifying some pertinent features of macroeconomic disorder in developing economies. Next, a simple model of the transmission mechanism is outlined, and applied to case material on the Jamaican economy to demonstrate the influence of macroeconomic disequilibria on Jamaica's rural financial market. Some conclusions are drawn in the final section.

\section{Pertinent Features of Macroeconomic Disorder}

Serious macroeconomic disorder in a developing economy may take one or more of the following forms. The economy typically experiences rapid rates of domestic price inflation. Price controls become increasingly ineffective in restraining the growth of consumer prices. Government subsidies fail to maintain a restraining influence because the inflation erodes the purchasing power of government itself. However, domestic agricultural prices tend not to rise as rapidly as 
the general level of prices, since governments for sociopolitical reasons adopt price controls and food import policies to prevent the full upward adjustment of domestic food prices. Consequent1y, domestic food producers tend to experience a deterioration in their terms of trade. To the extent that exogeneously determined export agricultural prices rise more slowly than domestic prices, export producers also experience declines in their terms of trade.

Factor costs also tend to escalate. Money wage rates respond to consumer prices with a lag, the length of which depends on the degree and strength of unionization. While the domestic foodstuffs subsector is significantly less unionized than the non-agricultural sectors, workers in export agriculture are highly unionized. A wage spread or spillover mechanism links wage rates in the two agricultural subsectors such that the unionized wage rate in the export subsector "pulls up" the nonunionized wage rate for domestic agriculture. The price of capital services will also tend to rise if severe balance of payments pressure results in exchange rate devaluation which increases the import prices of agricultural inputs such as fertilizers, chemicals, and machinery, or in quantitative restrictions on imports which by creating supply shortages drive up local supply prices. Government subsidies on chemica1 or other inputs might also be reduced. The user cost of capital services will consequently tend to rise in this disequilibrium situation.

Quantitative restrictions on imports tend to be utilized as an instrument of balance of payments correction (e.g. Krueger). Quantitative restrictions on imports of producer goods, in the face of inelastic domestic supplies, result in reduced availabilities of those goods. 
The agricultural sector is affected to the extent that the restrictions apply to its range of producer goods. In practice, supplies of modern agricultural inputs are adversely affected by extensive quantitative restrictions on imports.

Nominal interest rates tend to increase as financial institutions attempt to defend their profit rates against rising factor costs. Short run rigidity in deposit costs, resulting from contractual time deposit arrangements, would ensure that loan rates would be defensively raised by commercial lending institutions.

Finally, acute deterioration in the country's balance of international payments ultimately forces the adoption of stabilization programs formulated with the assistance of multilateral agencies, notably the International Monetary Fund. The stabilization programs usually incorporate provisions for sizable exchange rate devaluation and for monetary and credit restraint (Maynard and Bird; Kafka; Reichman and Stillson). Characteristic of the later stages of serious economic disorder, therefore, are devaluation-induced increases in the local currency value of debt denominated in foreign currency, and policy determined contractions in credit supply.

\section{A Simple Mode1 of the Transmission Mechanism}

The effects of severe macroeconomic disorder on rural financial markets are transmitted through changes in farm savings and debt transactions induced by the rising costs of farm production and consumption relative to agricultural product prices. The following simple model illustrates the main aspects of the transmission mechanism. 
Assume that farm operations can be described by the following set of production, profits, income-expenditure, and debt relationships.

Farm output is represented by the linear production function:

$$
Q=f_{1} K+f_{2} N
$$

where $Q$ is output per acre, $K$ is capital services inclusive of planting materials and chemicals per acre, and $\mathrm{N}$ is labor per acre. The $\mathrm{f}_{i}$ are production coefficients.

The farm's gross profits relationship is:

$$
\mathrm{Y}=\mathrm{p}_{1} \mathrm{Q}-\mathrm{p}_{2} \mathrm{~K}-\mathrm{p}_{3} \mathrm{~N}
$$

where $\mathrm{Y}$ is gross profits, $\mathrm{p}_{1}$ is product price, $\mathrm{p}_{2}$ is the cost of capital services, and $\mathrm{p}_{3}$ is the money wage rate.

This specification of the gross profits function implicitly assumes that there are no factor payments for 1and. A1though in practice some form of rental arrangement may exist, we simplify by assuming that farmers own the land they cultivate. It is also assumed that family labor is incorporated in $\mathrm{N}$ and is paid at the market wage rate, $\mathrm{P}_{3}$.

The cost of capital services is susceptible to quite complex expressions depending on the assumptions made about the rate of capital stock depreciation, income taxes, and discount rates. In its simplest form, the user cost of capital can be expressed as the price of capital goods. In developing economies, two main determinants of capital good prices would be the local currency cost of imported capital goods and the degree of quantity rationing. Quantity rationing creates excess demand pressures which tend to drive prices up. 
Gross profits are used for tax payments, $T$, debt service and amortization, D, farm consumption, C, and savings, S. It is assumed that the sole tax levied on farmers is a flat annual charge per acre of 1and owned. Tax payments are therefore a fixed charge on gross profits. It is also assumed that farmers treat farm consumption as a first order claim on gross income. These two assumptions imply that actual debt payments and savings are residua11y determined:

$$
\mathrm{D}+\mathrm{S}=\mathrm{Y}-\mathrm{T}-\mathrm{C}
$$

The farm's demand for debt $\left(L^{d}\right)$ is hypothesized to vary negatively with current farm gross income, positively with expected gross income, negatively with the interest cost of credit, $i$, and negatively with the amount of own financial resources, 1.e., S:

$$
L^{d}=L\left(Y, Y^{e}, 1 ; S\right)
$$

The negative relationship between actual income and credit demand is rationalized on the grounds that the greater the farm's net cash flow the lower the liquidity demand for credit. The expected income variable is justified on traditional accelerator and expected profits grounds. Finally, the farm satisfies the balance sheet condition that tota1 assets must equal total 1iabilities:

$$
\mathrm{S}+\mathrm{A}=\mathrm{L}
$$

where $A$ is accumulated assets at time $t$.

To complete the model, one needs to specify the price relationships. Consistent with the earlier discussion of the macroeconomy, farm product prices are assumed to be determined as follows:

$$
\mathrm{p}_{1}=\mathrm{w}_{1} \mathrm{gP}+\mathrm{w}_{2} \mathrm{P}_{\mathrm{x}}
$$


where $w_{i}$ are weights for the share of domestic agriculture and export agriculture in total agricultural output. $g$ is the fixed coefficient less than unity which government applies to the overall price leve1, P, to determine domestic agricultural prices. $\mathrm{P}_{\mathrm{x}}$ is the exogeneously determined local currency price of agricultural exports. ${ }^{1}$

The cost of capital services is directly related to the local currency price of imports, $\mathrm{p}_{\mathrm{m}}$, and the degree of quantity restriction, $\mathrm{R}$.

$$
\mathrm{p}_{2}=\mathrm{a}_{1} \mathrm{p}_{\mathrm{m}}+\mathrm{a}_{2} \mathrm{R}
$$

The wage rate is a direct function of the overall price level:

$$
\mathrm{p}_{3}=\mathrm{bP}
$$

The overall level of prices itself is determined by import prices and by the level of excess aggregate demand:

$$
\mathrm{P}=\mathrm{e}_{1} \mathrm{p}_{\mathrm{m}}+\mathrm{e}_{2} \mathrm{ED}
$$

where ED is excess demand.

Fina11y, the price of credit is the rate of interest, $r$, adjusted for changes in the capital value of the debt:

$$
i=r+k
$$

where $k$ is the percentage change in the capital value of debt.

By combining equations (1), (2), and (6) to (9), and differentiating gross profits with respect to the general price leve1, one can identify the effects of price inflation on gross farm profits

$$
\begin{aligned}
\frac{d Y}{d P} & =w_{1} g\left(f_{1} K+f_{2} N\right)-b N \\
& =w_{1} g f_{1} K+\left(w_{1} g f_{2}-b\right) N
\end{aligned}
$$


It can be seen that the effects of general price inflation on gross profits depends on the input-output coefficients $f_{1}$, the government agricultural pricing rate, $g$, the share of domestic agricultural output, $w_{1}$, and the wage-price coefficient, $b$. If the input-output relationships and domestic agriculture's share are unchanged, then domestic price inflation will depress profits if adjustment is fuller for wages than for domestic agricultural prices.

It can be shown that $d Y / d p_{m}=-a_{1} K<0$. Thus import price inflation operating through the price of agricultural capital goods increases the cost of capital services and depresses profits. Quantity restrictions a1so depress profits since $d Y / d R=a_{2} K<0$, and through the reduced availability of capital services for production.

Recognizing that the money value of consumption increases with the rate of inflation, given fixed real consumption targets, domestic price inflation increases $C$ in this model.

Altogether, therefore, price trends and import restraints reduce the avallability of incomes for debt payments and savings. Lower levels of farm savings impinge negatively on the flow of loanable funds into those rural financial institutions which mobilize rural surpluses. This is one adverse consequence of severe economic disorder for rural financial market performance. Another is the growing delinquency and loan default caused by the depressing effects of general and factor price inflation on debt service and amortization capacity.

Paradoxically, the ability to service debt is reduced at times when the stabilization program increases debt service requirements by 
raising the interest rate, $r$, and the local currency value of loans provided out of foreign currency resources. The change in local currency value of debt would tend to be significant for that segment of rural financial markets made up of public sector specialized credit agencies, funded largely by loans from foreign governments and multilateral agencies.

On examination of the demand for credit function, one would predict that farm demand for credit is reduced by domestic consumer and factor price inflation which adversely affect profit expectations and by the rising cost of credit occasioned by the stabilization program. However, there are also pressures in the opposite direction. The 1iquidity demand for credit is increased by the fall in current profits and current savings. The net outcome on credit demand would depend on the relative strength of these two sets of tendencies. If the credit stabilization program is effective, export credit supply would tend to be lower, a tendency that would itself be strengthened by the loan-capacity depressing effects of reduced levels of savings.

On balance, it can be concluded on theoretical grounds that, by impacting negatively on farm savings, debt creation, and debt payments, severe macroeconomic disorder is likely to exert a depressing effect on rural financial markets in developing economies.

Jamaican Rural Financial Market Depression

The Jamaican economy provides excellent case material for applying the principles developed in the preceding section. ${ }^{2}$ The economy 
collapsed from a situation of positive growth of real gross domestic product averaging 5 percent during 1965 to 1972 to an uninterrupted succession of annual negative growth rates ranging from 1 to 8 percent between 1974 and 1978. Prolonged balance of payments problems, manifested by a movement from net foreign reserves of $\mathrm{J} \$ 132$ million in 1971 to minus J\$196 mi11ion in 1977, resulted in increasing1y severe corrective policles of quantitative restrictions on imports, exchange rate devaluations totaling 54 percent between 1970 and 1978, and domestic credit restraint. The economy is heavily reliant on imports for its supply of consumer and producer goods, with imports averaging 41 percent of gross national expenditure over the period. Consequently, domestic prices are highly responsive to changes in import prices. The rate of inflation has risen sharply, averaging 15 percent during the 1970s, and was as high as 27 percent in 1978 . Labor is highly unionized in all productive sectors, excluding domestic agriculture. Wage rates have generally kept pace with domestic price inflation.

On all counts, severe macroeconomic disorder typifies the Jamaican economy in the 1970s. The poor performance of the real sector was accompanied by serious problems within the financial sector, including the rural financial market. The rural financial market will now be briefly described, and its depression indexed. ${ }^{3}$

The institutional complex that comprises the Jamaican rural financial market includes eight commercial banks operating a countrywide network of branches, and two specialized government-owned credit 
agencies, namely the Jamaica Development Bank and the Agricultural Credit Board. Commercial banks are the largest single source of credit as well as the main savings institutions. The Agricultural Credit Board is a non-deposit taking institution established solely for the purpose of making direct loans to large farmers and institutional loans to the national network of People's Cooperative Banks, which in turn make small loans to small farmers. The People's Cooperative Banks also mobilize rural savings but on a very small scale. The Jamaica Development Bank, established in 1969, is funded mainly through capital subscriptions and loans from the Jamaican Government and from loans from foreign aid agencies. The Jamaica Development Bank operates a commercial loan window for medium to large farmers and, through an affiliated agency i.e. the Self-Supporting Farmers Development Program, maintains a loan facility for small to medium sized farmers. The Ministry of Agriculture provides rural credit services under several ad hoc programs, the most recent and important being the Crop Lien Program launched in 1977 to provide production loans to domestic foodcrop producers. Other financial institutions, such as building societies and life insurance companies, and informal groups such as rotating credit associations and credit unions complete the institutional structure of the rural financial market in Jamaica. While the rural savings and credit activities of the latter set of transactors cannot be precisely quantified, it does appear that most of rural savings and credit are channelled through the commercial banks and specialized government programs. The ensuing discussion of rural financial market depression is focused on the commercial banks, the Jamaica Development Bank and the Self Supporting Farmers Development Program. 
Three pertinent indicators of financial market performance are the behaviour of savings, credit, and loan repayments. Time series estimates of rural savings in Jamaica are not available. However, the behaviour of commercial bank total savings and time deposits provides some insight into the trends in rural savings mobilization. Real savings and time deposits after rising from $\mathrm{J} \$ 223$ million in 1970 to $\mathrm{J} \$ 298$ million in 1972, declined by 18 percent over the next two years, recovered slightly in 1975 and 1976, only to decline by roughly 7 percent in 1977. Overall, real savings at commercial banks stagnated from 1973 to 1978 (Table 1, Col. 1). Therefore, it can be inferred that the savings side of the Jamaican rural financial market did not perform well during this period. Rural credit, having expanded rapidly early in the 1970s, tended to decline after 1974. The time series of rural credit in Table 1 shows that the annual growth rate of credit (measured in constant 1970 prices) fell, negative growth being experienced in 1974 and dramatically so in 1978 (Column 4). The large percentage increase in 1975 is mainly a statistical artifact caused by officially reclassifying as "agricultural" many commercial bank loans which were previously classified as nonagricultural. The series on the ratio of rural credit to agricultural gross domestic product at factor cost exhibits the same pattern as the dollar values of rural credit, i.e. a rise and then a decline (Table 1 , Column 5).

Loan repayment data is not available for a sufficient number of years to permit similar trend analyses for loan repayment performance. However, the available information reveals a very unsatisfactory 
situation in 1977 and 1978 (Graham, Bourne, Begashaw). The ratio of arrears to payments due on Jamaica Development Bank commercial window loans reached system collapse levels of 81 and 83 percent in 1977 and 1978 respectively. The arrears ratio for the Self Supporting Farmers Development Program was as high as 38 percent in 1978. The commercial banks, largely because of their more stringent loan appraisal and recovery practices and their early write-off policy for bad debt, managed to keep their arrears ratio down to 4 percent in 1978. However, commercial banks did experience serious repayment problems. Their allowances for losses and bad debts as a proportion of total current operating expenses rose from an average of 4 percent between 1970 to 1975 to 6 percent between 1976 and 1977, and even higher to 11 percent in 1978. ${ }^{4}$ While these statistics on commercial bank performance do not pertain to agricultural loans exclusively, one may infer from these data that commercial banks, like the public sector credit agencies, were experiencing difficulties in recovering rural loans. The evidence on savings mobilization, credit, and loan repayment leads inescapably to the conclusion that Jamaican rural financial markets were very depressed in the 1970s, particularly in the latter half of the decade. Graham, Bourne and Begashaw have demonstrated that weaknesses in the design, implementation, and monitoring of rural credit programs explain much of this poor performance. However, these factors operating on the supply side, i.e. financial institutional side, do not fully account for the dismal experience. Events within the agricultural sector and within the overall economy seriously affected 
the demand side, i.e. the farm household side of the rural financial market, in ways that contributed to the difficulties experienced within the rural financial sector. The importance of these more general influences will now be demonstrated.

The Influence of Macroeconomic Disorder

It can be shown that the price behaviour of the economy contributed to the debt repayment problems experienced by Jamaican farmers. Selected price data are presented in Table 2. Examining first the series for the consumer price index and the Gross Domestic Product deflator, it can be seen that domestic price inflation was rapid, averaging between 15 and 17 percent per annum during the decade. On the basis of the wage-price relationship prevailing in this economy, one could infer that agricultural wage rates along with other wage rates rose rapidly in response to the inflation of consumer prices. Annual wage settlements for all sectors of the economy during the period 1971 to 1976 ranged between 18 and 45 percent. ${ }^{5}$ Economy-wide labor incomes per worker increased annually by an average of 18 percent. Agricultural incomes kept pace with the economy-wide trends. While no details are available on agricultural wage rates specifically, it is clear that per worker compensation of employees in the agricultural sector rose significantly (Table 2, Column 3), exceeding the national rate of increase of income per worker in 1975 and 1978. To some extent, the annual rate of increase since 1976 was restrained by the growing share of government sector agricultural employees in total agricultural employment. Since wage rate increases were slower for government 
employees, the composite index indicates slower rates of increases than actually obtained for privately employed agricultural workers.

The price of capital services also increased significantly over the period. The import price index (Table 2, Column 4) rose by an average of 23 percent per annum. It can be seen that the annual increases were particularly large in 1973, 1974, 1977 and 1978. Substantial exchange rate devaluations occurred in the first and last two of these four years, while in 1974 OPEC raised petroleum prices substantially. Further, more direct support for the contention that the price of capital services increased greatly is provided by the data on unit prices of imported chemical fertilizers (Table 2, Column 5). The annual increases averaged 28 percent, and in 1974 more than doubled, again largely as a result of OPEC's impact on the price of petroleum and petroleum-based products. It can be concluded, therefore, that the price of capital services depressed gross agricultural profits. These factor price trends do not appear to have been offset by increases in farm productivity. In the export sector, the index of tons of cane harvested per acre declined almost continuously from 100 in 1970 to 85 in 1977 (Table 3, Column 5). Productivity per acre in domestic agriculture remained roughly the same from 1971 to 1976 , but seems to have risen significantly in 1977 and 1978 (Table 3, Column 6).

Quantitative restrictions also reduced farm profits. Import licensing became increasingly widespread and severe, with consequent reductions in the availability of producer goods. For example, Table 2, Column 6 shows that the quantity index of fertilizer imports 
declined during the decade. The smaller supplies of improved inputs must have adversely affected production and productivity, and thereby farm revenues. The index of domestic food crop production declined slightly from 149 in 1972 and did not regain that level again until 1977 and 1978 when the massive governmental credit and physical support under the Emergency Production Plan succeeded in raising the index to 180 and 228 respectively (Table 3, Column 4). During this period, output decreased for the major agricultural export commodities, i.e. sugar and bananas by between 33 and 42 percent, and for quantitatively minor export commodities such as coffee (Table 3 , Columns $1,2,3$ ).

Given these adverse trends in factor prices, output, and productivity, it is necessary to examine the behaviour of agricultural commodity prices. Data on agricultural exports and farm-gate prices are summarized in Table 4. From Columns 1 and 2, it can be deduced that export prices rose on average more slowly than factor prices, adjusted for productivity declines. For instance, average annual percentage increases in the export prices of sugar and bananas, the two main export crops, were 20 and 18 percent respectively compared to an average annual price increase of 28 percent for fertilizers. Domestic agriculture seems to have fared no better. Column 3 reports an average annual percentage increase of 20 percent for domestic farm-gate prices. It should be noted that farm-gate prices actually declined in 1978.

The preceding analysis leads to the conclusion that the increases in product prices did not totally offset increases in factor prices, 
nor production and productivity declines. Consequently gross profits were serious1y squeezed. Direct evidence on profits reinforces this conclusion. The National Income and Product Accounts provide data on a reasonable proxy for profits, namely real operating surplus defined as value added minus net labor, tax, and capital consumption expenditures. Table 4 , Column 4 reveals that the real operating surplus of the agricultural sector declined in 1974, 1975, and 1978. In other words, agricultural gross profits were indeed reduced by the prevailing macroeconomic disorder.

The lower levels of gross income flows occurred at times when price trends in the economy increased the money value of farm household purchases. Unless farmers were willing to accept substantially lower real levels of consumption, the rapid rate of consumer price inflation would result in larger money allocations to farm household consumption. No data is presently available on farm consumption expenditures specifically. However, the National Accounts data revea1 that aggregate real private consumption expenditures did not fa11 unti1 1977 and 1978 when decreases of 4 and 10 percent were recorded. Most 1ikely, farm families shared that experience.

It has been argued so far that the macroeconomic disequilibria via product and factor prices, output, and productivity contributed to rural financial market depression by substantially reducing the capacity of farmers to save, make profitable investments, and to repay debt. It will now be shown that debt service and amortization requirements also increased. 
Commercial banks increased their loan rates of interest in an attempt to moderate the decline in net earnings caused by lower volumes of lending. On average, their nominal loan rates during 1974 to 1978 were three index points higher than rates in the 1970 to 1974 period (Bank of Jamaica Annual Report). Loan charges of public sector credit agencies remained the same (Graham, Bourne, Begashaw). However, given the large share of commercial banks in rural credit, overall rural loan rates of interest were pulled upwards. Furthermore, frequent exchange rate devaluations, totalling 54 percent between 1970 and 1978, increased the local currency value of debt financed from foreign funds. Farmers are required to maintain the foreign currency values of such loans made by the Jamaica Development Bank. Consequently, exchange rate devaluation abruptly increases the local currency costs of these debts. Foreign funds comprised between 33 and 67 percent of loans extended by the Jamaica Development Bank during the period 1970 to 1978. Farm credit extended by other institutions are not based on foreign funds and consequently have been unaffected by the recent devaluations. Nonetheless, given the share of the Jamaica Development Bank program in the total supply of rural credit, a substantial proportion of farm debt must have been adversely affected.

\section{Conclusion}

The central thesis of this article is that severe macroeconomic disequilibria and its adverse effects on the agricultural sector are major reasons for the poor performance of rural financial markets in 
developing economies. Failure to recognize the implications of general economic performance for the behavior of the rural economy and rural financial markets can result in policies that are directed only towards financial institutions. However, policies aimed at improving credit delivery, loan appraisal, and loan monitoring systems are too partial in scope to compensate for the more fundamental problems created by widespread disequilibria in product and factor markets and by balance of payments corrective policies. It is only by explicitly taking account of the general equilibrium framework in which rural financial markets function that effective policies can be devised.

The theoretical and empirical analysis in this paper demonstrates that the systematic application of even a very simple transmission model, which focuses on key production, price and expenditure relationships can contribute towards the formulation of appropriate policies. In the Jamaican case, the evidence strongly supports the contention that the poor performance of rural financial markets towards the end of the 1970s results substantially from serious macroeconomic disequilibria in that economy. It follows, then, that any successful program for improving the performance of those markets must include policies for general price and exchange rate stability. Only then can an appropriate balance between farm revenues and expenditures, including credit costs be restored. Without such a balance, rural financial markets are unlikely to perform effectively and efficiently. 
Table 1

Indicators of Financial Market Performance

in Jamaica, 1971-78

\begin{tabular}{|c|c|c|c|c|c|c|}
\hline \multirow[t]{2}{*}{ Year } & \multicolumn{2}{|c|}{$\begin{array}{c}\text { Real Savings } \\
\text { and Time Deposits } \\
\text { in Commercial } \\
\text { Banks } \\
\end{array}$} & \multicolumn{2}{|c|}{$\begin{array}{c}\text { Real } \\
\text { Rural Credit }\end{array}$} & \multicolumn{2}{|c|}{$\begin{array}{c}\text { Ratio of Real } \\
\text { Rural to Agric. } \\
\text { GDP at Factor Cost }\end{array}$} \\
\hline & $\$ M$ & $8 \Delta$ & $\$ M$ & $8 \Delta$ & Ratio & $8 \Delta$ \\
\hline & (1) & (2) & (3) & (4) & (5) & (6) \\
\hline 1971 & 256 & 15 & 29 & 13 & .33 & 5 \\
\hline 1972 & 298 & 16 & 32 & 12 & .35 & 8 \\
\hline 1973 & 280 & -6 & 37 & 15 & .44 & 24 \\
\hline 1974 & 245 & -12 & 35 & -6 & .41 & -6 \\
\hline 1975 & 257 & 5 & 56 & 60 & .64 & 56 \\
\hline 1976 & 262 & 2 & 61 & 10 & .73 & 14 \\
\hline 1977 & 244 & -7 & 65 & 7 & .73 & 0 \\
\hline 1978 & 258 & 5 & 43 & -35 & .44 & -39 \\
\hline
\end{tabular}

Source: Column 1 computed from data in Bank of Jamaica Statistical Digest. Column 3 computed from data in Jamaica Development Bank annual reports and files, and Jamaica Dept. of Statistics Monetary Statistics; column 5 from National Income and Product Accounts.

Notes: 1. Money values are deflated by Implicit GDP deflator, $1970=100$.

2. Rural Credit is the sum of agricultural loans outstanding by commercial banks, the Jamaica Development Bank, the Agricultural Credit Board, the Self-supporting Farmers Development Program, and the Crop Lien Program, deflated by the Implicit GDP deflator, $1970=100$. 
Table 2

Annual Percentage Changes in General Prices, Input Costs, and Input Supply for Jamaica, 1971-78

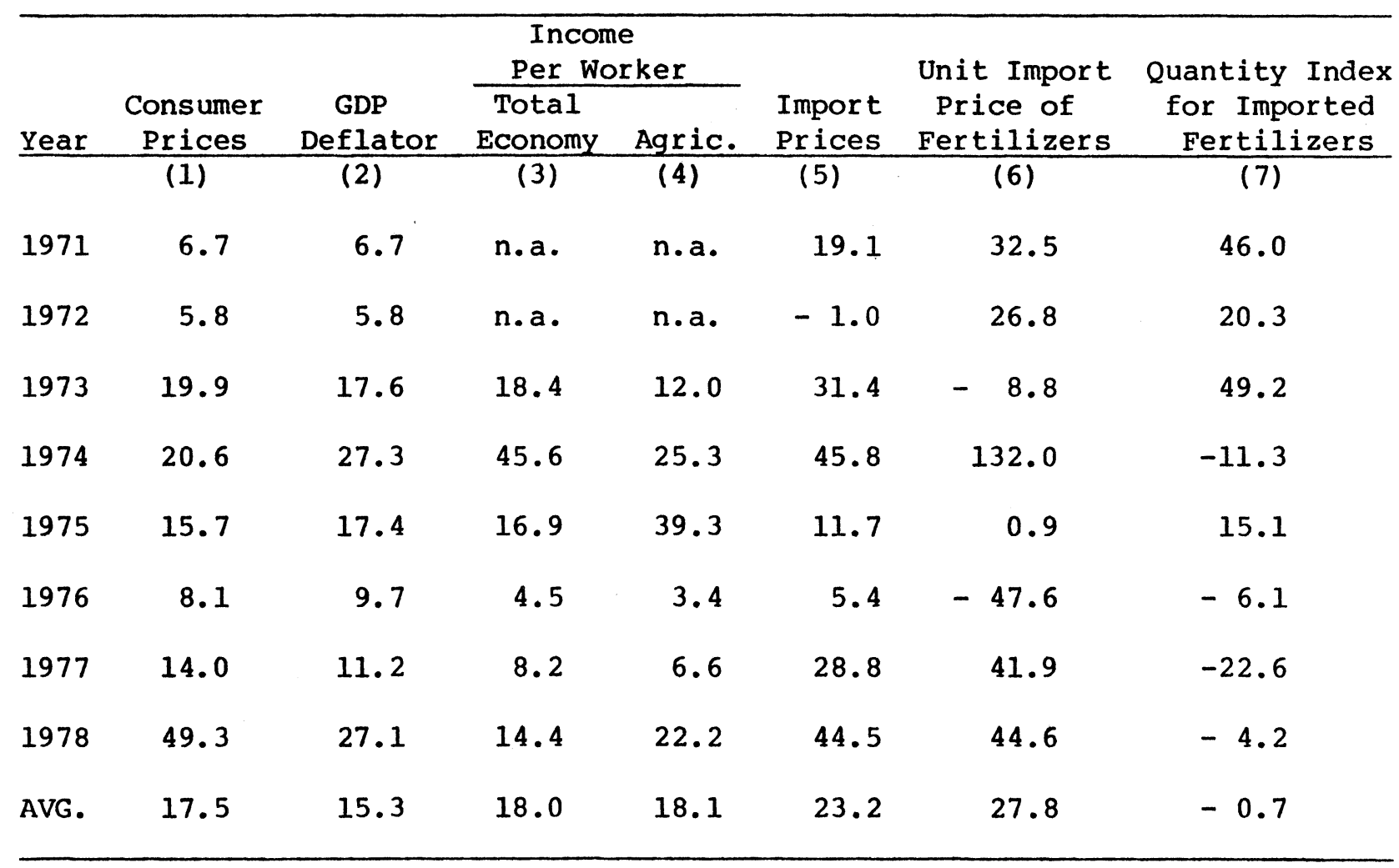

Source: Column 1 computed from data in Bank of Jamaica Statistical Bulletin. Remaining columns computed from data in Jamaica Dept. of Statistics External Trade Reports, National Income and Product Accounts, and The Labor Force. 
Table 3

Indices of Jamaican Agricultural Output and Productivity, Selected Crops 1971-78

$(1970=100)$

\begin{tabular}{|c|c|c|c|c|c|c|}
\hline \multirow[b]{2}{*}{ Year } & \multicolumn{4}{|c|}{ Output } & \multicolumn{2}{|c|}{ Land Productivity } \\
\hline & Sugar & Bananas & Coffee & $\begin{array}{l}\text { Domestic } \\
\text { Food Crops }\end{array}$ & $\begin{array}{l}\text { Sugar } \\
\text { Cane }\end{array}$ & $\begin{array}{l}\text { Domestic } \\
\text { Food Crops }\end{array}$ \\
\hline & (1) & (2) & (3) & (4) & (5) & (6) \\
\hline 1970 & 100 & 100 & 100 & 100 & 100 & 100 \\
\hline 1971 & 102 & 94 & 97 & 141 & 95 & 107 \\
\hline 1972 & 101 & 95 & 82 & 149 & 92 & 105 \\
\hline 1973 & 88 & 80 & 56 & 136 & 91 & 107 \\
\hline 1974 & 99 & 53 & 17 & 148 & 90 & 109 \\
\hline 1975 & 96 & 52 & 27 & 149 & 84 & 114 \\
\hline 1976 & 98 & 59 & 4 & 146 & 87 & 107 \\
\hline 1977 & 78 & 60 & 125 & 180 & 85 & 119 \\
\hline 1978 & 77 & 58 & 72 & 228 & 94 & 121 \\
\hline
\end{tabular}

Source: Columns 1, 2, 3, and 5 computed from data in annual Jamaica Economic and Social Survey (National Planning Unit); Column 4 and 6 computed from data in Ministry of Agriculture Indices of Domestic Agricultural Production and Farm Gate Prices, various years; and Jamaica Department of Statistics Statistical Yearbook of Jamaica, 1978. 
Table 4

Annual Percentage Changes in Agricultural Product Prices and Agricultural Operating Surpluses for Jamaica, 1971-78

\begin{tabular}{|c|c|c|c|c|}
\hline Year & $\begin{array}{c}\text { Export } \\
\text { Price of } \\
\text { Sugar } \\
\end{array}$ & $\begin{array}{c}\text { Export } \\
\text { Price of } \\
\text { Bananas }\end{array}$ & $\begin{array}{c}\text { Farm-Gate } \\
\text { Prices }\end{array}$ & $\begin{array}{l}\text { Real } \\
\text { Gross } \\
\text { Profits } \\
\end{array}$ \\
\hline & (1) & $(2)$ & (3) & (4) \\
\hline 1971 & 3.0 & 6.0 & 22.8 & 23.6 \\
\hline 1972 & 22.3 & 0 & 1.9 & 2.4 \\
\hline 1973 & 11.1 & 62.3 & 36.6 & 7.3 \\
\hline 1974 & 31.4 & 4.6 & 32.7 & -4.8 \\
\hline 1975 & 100.0 & 35.5 & 26.1 & -3.9 \\
\hline 1976 & -56.0 & -27.9 & 8.4 & 1.1 \\
\hline 1977 & 31.6 & 43.7 & 35.3 & 5.7 \\
\hline 1978 & n.a. & n.a. & -1.6 & -8.0 \\
\hline AVG. & 20.4 & 17.7 & 20.3 & 2.9 \\
\hline
\end{tabular}

Source: Columns 1 and 2 computed from data in Bank of Jamaica Balance of Payments Accounts; Column 3 from Ministry of Agriculture Indices of Domestic Agricultural Production and Farm-Gate Prices; and Column 4 from Dept. of Statistics National Income and Product Accounts. 


\section{Notes}

* We gratefully acknowledge the advice of Dale W Adams and Robert C. Vogel.

1 A practical, but for present purposes unncessary, refinement would be to express export prices paid to farmers as a proportion of the prices received by centralized export marketing agencies.

2 The empirical evidence in this paragraph is based on data series obtainable from three official publications, namely: Jamaica Department of Statistics National Income and Product Accounts, Bank of Jamaica Annual Report, Bank of Jamaica Statistical Digest.

3 Graham, Bourne, and Begashaw contain a fuller description and analysis.

4 These computations are based on costs and earnings data published in Jamaica Department of Statistics Monetary Statistics, 1978.

5 These data, reported in Bank of Jamaica Annual Reports, include wage awards which, though approved in a given year, pertain to union wage contracts of more than one year duration. In such cases, the settlements recorded overstate the actual wage increase for that year. 


\section{References}

1. Adams, Dale $\mathrm{W}$ "Mobilizing Household Savings Through Rural Financial Markets", Economic Development and Cu1tural Change 26, 3, 1978: $547-60$.

2.

"Recent Performance of Rural Financial Markets in Low Income Countries". ESO 596, Department of Agricultural Economics and Rural Sociology, The Ohio State University, Apri1, 1979.

3. Adams, Dale W and J. R. Ladman. "The Rura1 Poor and the Recent Performance of Formal Rural Financial Markets in the Dominican Republic", Canadian Journal of Agricultural Economics, 26, 1, 1978: 43-50.

4. "Lending to Rura1 Poor Through Informal Groups: A Promising Financial Market Innovation?", Savings and Development 3, 2, 1979.

5. Datey, C. D. The Financial Cost of Indian Agricultural Credit: A Case Study of Indian Experience. World Bank Staff Working Paper No. 296, October 1978.

6. DeAraujo, Paulo F. C. and Richard L. Meyer. "Agricultural Credit Policy in Brazil: Objectives and Results", American Journal of Agricultural Economics 59, 5, 1977: 957-61.

7. Desai, B. M. "Rural Banking in India and Its Performance and Problems" in Problems and Issues of Agricultura1 Credit and Rural Finance, Bangladesh Bank, Decca 1979.

8. Gonzalez-Vega, Claudio and Ronald L. Tinnermeir. Invierno: Innovation in Credit and in Rural Development. Occasional Paper No. 8, Economics and Sector Planning Division, Agency for Internationa1 Development, Washington, D. C., 1979.

9. Graham, Douglas, Compton Bourne, and Girma Begashaw. Economic Growth and Rural Financial Markets in Jamaica: Analysis of Performance, Problems and Recommendations. Studies in Rura1 Finance, Agricultura1 Finance Program, The Ohio State University, 1978 .

10. Kafka, A. "Adjustment Under the Bretton Woods Code With Special Reference to the Less Developed Countries" in Development and Planning (ed. J. N. Bhagwati and R. S. Eckaus), London, A11en and Unwin, 1972. 
11. Krueger, Anne 0. Liberalization Attempts and Consequences. New York, National Bureau of Economic Research, Ballinger Publishing Co., 1978.

12. Ladman, Jerry R. and Ronald Tinnermeir. "Credit Policies and Rura1 Financial Markets in Bolivia", American Journal of Agricultura1 Economics 59, 5, 1977: 962-66.

13. Maynard, E. W. and G. R. Bird. "International Monetary Issues and the Developing Countries: A Survey", World Development 4, 9, 1975.

14. Reichman, Thomas M. and Richard T. Stillson. "Experience with Programs of Balance of Payments Adjustment: Standby Arrangements in the Higher Credit Trenches", International Monetary Fund Staff Papers 25, 2, 1978: 293-309.

15. Voge1, Robert C. "The Effect of Subsidized Agricultural Credit on the Distribution of Income in Costa Rica", unpublished, Southern Illinois University, 1977. 